\title{
PENGEMBANGAN MEDIA PEMBELAJARAN BERBASIS VIDEO PADA TEORI PEMESINAN FRAIS
}

\author{
Muhammad Aziz Fauzan ${ }^{1}$, Dwi Rahdiyanta ${ }^{2}$ \\ ${ }^{1,2}$ Pendidikan Teknik Mesin, Fakultas Teknik, Universitas Negeri Yogyakarta \\ muhammadazizfauzan@gmail.com
}

\begin{abstract}
This research is intended to produce a suitable video-based learning media on the making of helical gear in Milling Theory. This is a Research and Development type research incorporating six steps, namely: stating the potentials and problems, collecting data, designing the product, validation of the product design, revision of the design and product trials. Feasibility of the learning media was assesed by content-expert, media expert, teachers and students, by means of questionnaires. The quantitative research data were analized using quantitative-descriptive analysis technique. The product of this research is a learning media in the form of mp4 videos about Milling Machining practice. The media includes introductory music, videos, naration and animation. The feasibility level of the video-based learning media were assessed and presented in the form of percentages and classifications. The content-expert gave a feasibility level of $96.50 \%$ with classification of "very good", the media-expert gave 80.63\% with classification of "very good", the teacher gave 76.25\% with classification "very good" and the students" responses reached $80.52 \%$ with classification of "strongly agree" to the use of the video-based learning media. It can be concluded that the video-based learning media of Milling Machining Theory is feasible to use in the teaching and learning process.
\end{abstract}

Keywords research and development, milling machining theory, video-based learning media

\begin{abstract}
ABSTRAK
Penelitian ini bertujuan untuk menghasilkan produk berupa media pembelajaran berbasis video pembuatan roda gigi heliks pada Teori Pemesinan Frais yang layak digunakan. Penelitian ini merupakan penelitian pengembangan dengan enam tahap, yaitu: potensi dan masalah, pengumpulan data, desain produk, validasi desain, revisi desain dan uji coba produk. Kelayakan media pembelajaran dinilai menggunakan angket oleh ahli materi, ahli media, guru pengampu dan siswa. Data penelitian berupa data kuantitatif yang dianalisis menggunakan teknik analisis deskriptif kuantitatif. Hasil penelitian berupa produk media pembelajaran Teknik Pemesinan Frais berbasis video berbentuk file mp4 yang dilengkapi dengan musik pengantar, video, narator dan animasi. Kelayakan media pembelajaran berbasis video dari ahli materi diperoleh persentase sebesar $96.50 \%$ dengan klasifikasi sangat baik, dari ahli media diperoleh persentase sebesar $80.63 \%$ dengan klasifikasi sangat baik, dari guru pengampu diperoleh persentase sebesar $76.25 \%$ dengan klasifikasi sangat baik dan berdasarkan respon penilaian siswa diperoleh persentase sebesar $80.52 \%$ dengan klasifikasi sangat setuju menggunakan media pembelajaran ini. Dengan demikian media pembelajaran berbasis video pada Teori Pemesinan Frais layak digunakan untuk proses pembelajaran.
\end{abstract}

Kata kunci: penelitian dan pengembangan, teori pemesinan frais, media pembelajaran berbasis video

\section{PENDAHULUAN}

Pendidikan adalah bagian penting dalam kehidupan manusia. Menurut Sukoco (2014: 216) pendidikan adalah dilakukan oleh orang dewasa termasuk di dalamnya guru, membantu anak didik mencapai tujuan yang diinginkan. Sekolah Menengah Kejuruan (SMK) adalah salah satu lembaga pendidikan yang menghasilkan lulusan siap terjun didunia kerja. Undang-Undang Republik Indonesia Nomor
20 Tahun 2003 tentang Sistem Pendidikan Nasional pada Pasal 15 mengemukakan bahwa pendidikan kejuruan merupakan pendidikan menengah yang mempersiapkan peserta didik terutama untuk bekerja dalam bidang tertentu. Djatmiko (2013: 9) menyatakan bahwa pendidikan vokasi adalah pendidikan yang menyiapkan terbentuknya keterampilan, kecakapan, pengertian, perilaku, sikap, kebiasaan kerja dan apresiasi terhadap 
pekerjaan-pekerjaan yang dibutuhkan oleh masyarakat dunia usaha/industri.

Dalam pendidikan kejuruan sangat diperlukan adanya proses pembelajaran yang baik, sehingga materi yang diberikan pengajar dapat diterima oleh siswa. Metode penyampaian materi oleh guru juga mempengaruhi tersampainya materi pembelajaran kepada siswa. Dalam hal ini siswa juga harus bisa fokus terhadap mata pelajaran yang sedang di pelajari atau disampaikan oleh guru.

Kenyataan yang diperoleh dari hasil observasi selama PPL di SMK N 2 Yogyakarta, ditemukan bahwa metode pembelajaran menggunakan metode ceramah, sehingga beberapa siswa jenuh terhadap pelajaran dan tidak fokus dengan materi yang disampaikan oleh guru. Senada dengan hal tersebut salah seorang guru mata pelajaran teori pemesinan frais juga mengatakan bahwa siswa kesulitan dalam pemahaman teori roda gigi heliks, sehingga membutuhkan waktu yang lama untuk menyampaikan materi dan dibutuhkan media pembelajaran.

Menurut Sadiman (2011: 7) media pembelajaran adalah segala sesuatu yang dapat digunakan untuk menyalurkan pesan dari pengirim ke penerima sehingga dapat merangsang pikiran, perasaaan, perhatian dan minat serta perhatian siswa sedemikian rupa sehingga proses belajar terjadi. Sanjaya (2012: 61) menyatakan bahwa media pembelajaran adalah segala sesuatu seperti alat, lingkungan dan segala bentuk kegiatan yang dikondisikan untuk menambah pengetahuan, mengubah sikap dan menanamkan keterampilan pada setiap orang yang memanfaatkannya.

Kehadiran media pembelajaran diharapkan mampu menghilangkan kejaenuhan siswa dalam belajar, sehingga siswa lebih fokus dalam pembelajaran. Menurut Mustholiq, dkk (2007: 6) media pembelajaran mempunyai peran yang penting dalam proses belajar mengajar, karena dapat membuat suasana belajar menjadi lebih hidup dan bermakna. Sudjana (2013: 2) media pembelajaran sangat bermanfaat dalam proses belajar siswa antara lain: (1) pengajaran lebih menarik perhatian siswa sehingga dapat menumbuhkan motivasi belajar; (2) bahan pelajaran akan lebih jelas maknanya sehingga dapat lebih dipahami oleh para siswa; (3) metode mengajar akan lebih bervariasi; (4) siswa lebih banyak

Tujuan penelitian ini yaitu menghasilkan produk berupa media pembelajaran berbasis video pada mata pelajaran teori pemesinan frais karena belum ada media pembelajaran berbasis video untuk mata pelajaran teori pemesinan frais. Media video dipilih sebagai media pembelajaran yang dikembangkan karena media video relatif lebih mudah dalam pengoperasiannya. Isi dari media pembelajaran yang dikembangkan adalah langkah-langkah pembuatan roda gigi heliks dan teori yang bersangkutan dengan roda gigi heliks serta dilengkapi musik pengantar, narator, dan animasi.

\section{METODE}

Penelitian ini merupakan penelitian dan pengembangan karena penelitian ini bertujuan untuk mengembangkan media pembelajaran berbasis video pada mata pelajaran Teori Pemesinan Frais dan mengetahui kelayakan media pembelajaran berbasis video pada mata pelajaran Teori Pemesinan Frais di SMK Negeri 2 Yogyakarta. Model penelitian dan pengembangan yang digunakan adalah model pengembangan Sugiyono (2011: 334) yang terdiri dari 10 tahap. Namun dikarenakan adanya beberapa revisi dan dalam penelitian ini untuk skala kecil maka penelitian ini hanya sampai pada langkah keenam yaitu: (1) potensi dan masalah, (2) pengumpulan data; (3) desain produk; (4) validasi desain meliputi; (5) revisi desain; (6) uji coba produk.

Penelitian pengembangan media pembelajaran pada mata pelajaran Teori Pemesinan Frais dilakukan pada tanggal 8 Februari 2017 sampai dengan 10 Juni 2017 di SMK N 2 Yogyakarta jalan A.M. Sangaji No. 
47 Yogyakarta. Subyek dari penelitian ini adalah siswa kelas XI TP3 jurusan Teknik Pemesinan SMK N 2 Yogyakarta tahun ajaran 2016/2017.

Prosedur penelitian pengembangan yang digunakan adalah model Sugiyono (2011: 334). Gambar 1 merupakan langkah yang digunakan pada model Sugiyono (2011: 334).

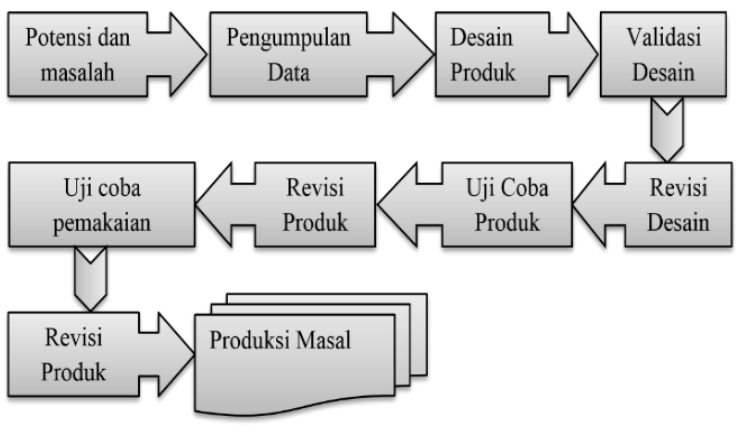

Gambar 1. Langkah-Langkah Pengembangan Media Pembelajaran

Dalam Gambar 1 terdapat 10 langkah penelitian dan pengembangan model Sugiyono (2011: 334), Namun dikarenakan adanya beberapa revisi dan dalam penelitian ini untuk skala kecil maka penelitian ini hanya sampai pada langkah keenam.

Potensi dan masalah, tahap potensi dan masalah merupakan tahap untuk mengetahui potensi dan masalah yang ada dan dilakukan dengan cara observasi. Observasi dilakukan ketika melaksanakan PPL di SMK N 2 Yogyakarta.

Pengumpulan data, data yang dikumpulkan antara lain: silabus, RPP, materi bahan ajar, gambar dan jobsheet roda gigi heliks. Data diperoleh dari buku dan internet. Setelah memperoleh data, kemudian data dipilih yang sesuai dengan silabus mata pelajaran teori pemesinan frais pada bahan ajar pembuatan roda gigi heliks.

Desain produk, tahap ini merupakan tahap perancangan kerangka produk media pembelajaran berbasis video yang akan dikembangkan. Produk media pembelajaran berbasis video dibuat dalam tiga tahapan, meliputi: 1) pra produksi, yang terdiri dari identifikasi masalah, pembuatan storyboard dan pembuatan naskah, 2) produksi, pada tahap ini dilakukan kegiatan shooting proses pembuatan roda gigi heliks di Bengkel Pemesinan Fakultas Teknik Universitas Negeri Yogyakarta, 3) pasca produksi, pada tahap ini dilakukan kegiatan editing video dan mastering/ finalisasi video.

Validasi desain, pada tahap ini dilakukan uji kalayakan media. Media pembelajaran diujikan kepada ahli materi pembelajaran, ahli media pembelajaran dan guru pengampu mata pelajaran teori pemesinan frais. Uji validitas dilakukan untuk mengetahui dan mengevaluasi media yang dikembangkan supaya sesuai dengan tujuan pembelajaran.

Revisi desain, tahap ini dilakukan perbaikan media pembelajaran sesuai saran/ masukan dari ahli materi pembelajaran, ahli media pembelajara dan guru pengampu mata pelajaran. Perbaikan media pembelajaran dilakukan supaya media pembelajaran dapat digunakan dan sesuai dengan silabus pembelajaran teori pemesinan frais SMK yang ada.

Uji coba produk, tahap ini dilakukan untuk mendapatkan respon dari siswa terhadap media pembelajaran yang dikembangakan. Pengambilan data dilakukan pada 32 siswa kelas XI TP 3 SMK N 2 Yogyakarta menggunakan instrumen berupa angket/ kuesioner.

Data yang diambil merupakan data hasil validasi ahli materi, ahli media, guru pengampu dan siswa. Instrumen yang digunakan berupa lembar validasi ahli dan kuesioner siswa. Teknik pengumpulan data dilakukan dengan observasi pada tahap potensi dan masalah, dokumentasi pada tahap pembuatan media dan kuesioner untuk memperoleh respon penilaian siswa.

Skala pengukuran menggunakan skala likert. Kriteria penilaian jawaban setiap item instrumen dengan skala likert yang memiliki bobot penilaian antara 1-4 dan alternatif jawaban berupa kurang baik, cukup baik, baik, 
dan "sangat baik pada instrumen penilaian ahli materi, ahli media, dan guru, sedangkan pada instrumen respon siswa menggunakan alternatif jawaban berupa sangat tidak setuju, tidak setuju, setuju, dan sangat setuju.

Teknik analisis data yang digunakan dalam penelitian ini yaitu teknik analisis deskriptif kuantitatif. Rumus yang digunakan dapat dilihat pada Persamaan (1).

Persentase Kelayakan $=$ $\frac{\text { Skor yang diobservasi }}{\text { Skor yang diharapkan }} \times 100 \%$

Persentase kelayakan dimaksudkan untuk mengetahui status tingkat interpretasi variabel seperti terlihat dalam Tabel 1.

Tabel 1. Tabel Skala Persentase

\begin{tabular}{ccc}
\hline Persentase & Skala & Interpretasi \\
Pencapaian $(\%)$ & Nilai & \\
\hline $76-100$ & 4 & Sangat Baik \\
$56-75$ & 3 & Baik \\
$25-55$ & 2 & Cukup Baik \\
$0-25$ & 1 & Kurang Baik \\
\hline
\end{tabular}

Tabel skala persentase digunakan untuk menentukan nilai kelayakan produk yang dihasilkan. Nilai kelayakan untuk produk pengembangan media pembelajaran berbasis video pada mata pelajaran Teori Pemesinan Frais ini ditetapkan kriteria kelayakan minimal baik atau mencapai persentase minimal 56\%.

\section{HASIL DAN PEMBAHASAN}

\section{Bentuk Produk Media Pembelajaran}

Bentuk produk media pembelajaran pada mata pelajaran teori teknik pemesinan frais dengan pokok bahasan roda gigi heliks adalah media pembelajaran berbasis video. Produk media ini menyuguhkan lima materi yaitu: tujuan pembelajaran, pengertian roda gigi heliks, fungsi roda gigi heliks, bagianbagian roda gigi heliks dan proses pebuatan roda gigi heliks. Media ini sangat praktis Karena berbentuk file $m p 4$ sehingga media ini dapat langsung digunakan dengan komputer atau laptop.
File media pembelajaran yang dikembangkan sebesar $166 \mathrm{MB}$ dan sangat mudah dijalankan meski menggunakan komputer dengan spesifikasi rendah. Selain itu media pembelajaran ini juga sangat mudah digunakan, karena tidak perlu keahlian khusus untuk mengaplikasikannya. Dalam pengoperasiannya, seperti memutar/ menjalankan vidio pada umumnya dan menggunakan navigasi pause yang terdapat dalam software pemutar video untuk menghentikan video sementara.

Secara struktur, media pembelajaran berbasis video ini memuat halaman menu utama yang berisi pokok bahasan yang akan dipelajari dalam media pembelajaran ini. Pokok bahasan yang terdapat dalam media ini yaitu, tujuan pembelajaran, pengertian roda gigi heliks, Bagian-bagian roda gigi heliks, fungsi roda gigi heliks dan proded pembuatan roda gigi heliks. Dalam tujuan pembelajaran, pengertian roda gigi heliks dan fungsi roda gigi heliks berisi tulisan-tulisan dengan warna background yang menarik. Pada pokok bahasan bagian-bagian roda gigi heliks dilengkapi gambar serta keterangan setiap bagiannya. Dan pada proses pembuatn roda gigi heliks terdiri dari langkah-langkah dalam pembuatan roda gigi heliks. Proses pembuatan roda gigi heliks berisikan video nyata pembuatan roda gigi heliks. Media ini juga dilengkapi dengan nerator sebagai penjelas penyampaian materi dan backsong supaya siswa tidak jenuh dalam mempelajari materi yang disampaikan. Pada bagian terakhir media ini terdapat informasi tentang media yang dikembangkan dan beberapa nama yang ikut berperan dalam pembuatan media.

Dalam penggunaanya media pembelajaran berbasis video termasuk sangat mudah untuk mengaplikasikannya, karena tidak memerlukan software khusus. Untuk orang awam yang belum terampil menggunakan komputer atau laptop juga tidak membutuhkan waktu yang lama untuk mempelajarinya. Ketika media sudah dijalankan, materi yang terdapat pada media 
akan terus berjalan seperti pemutaran video pada umumnya. Apabila ada materi yang penting untuk dipelajari dan akan menghentikan video, operator cukup memilih tombol pause yang terdapat pada software pemutar video atau menekan "spasi" pada keyboard. Setelah media selesai digunakan, operator cukup menekan tanda silang yang terdapat pada pojok kanan atas layar komputer/ laptop.

\section{Kelayakan Media Pembelajaran}

Kelayakan media pembelajaran berbasis video pada mata pelajaran Teori Pemesinan Frais diujikan pada tahap validasi ke ahli materi dan ahli media, serta penilaian guru pengampu untuk dinilai kelayakan dari beberapa aspek kelayakan. Kemudian media pembelajaran ditindaklanjuti sebagai perbaikan dan diujicobakan pada siswa kelas XI TP 3 SMK Negeri 2 Yogyakarta yang berjumlah 32 siswa menggunakan instrumen angket respon siswa yang sudah valid guna mendapatkan hasil penilaian berdasarkan respon siswa.

Penilaian kelayakan media pembelajaran berbasis video pada mata pelajaran Teori Pemesinan Frais dilaksanakan oleh ahli materi dinilai berdasarkan dua aspek yaitu aspek pendahuluan dan isi materi. Data hasil penilaian ahli media dilihat pada Tabel 2 .

Tabel 2. Hasil Penilaian Tiap Aspek oleh Ahli Materi

\begin{tabular}{cccl}
\hline No. & Aspek & 'ersentase $(\%$ & Klasifikasi \\
\hline 1. & Pendahuluan & 100 & Sangat Baik \\
2. & Isi Materi & 93 & Sangat Baik \\
\hline & Rata-rata & 96.50 & Sangat Baik \\
\hline
\end{tabular}

Hasil persentase kelayakan media yang diperoleh dari ahli materi untuk aspek pendahuluan adalah sebesar $100 \%$ termasuk pada klasifikasi sangat baik, untuk persentase kelayakan aspek isi materi adalah sebesar 93\% termasuk pada klasifikasi sangat baik. Hasil penilaian ahli media untuk penilaian seluruh aspek didapatkan hasil sebesar $96.50 \%$ dengan klasifikasi sangat baik dan disimpulkan bahwa media pembelajaran dinyatakan layak atau dapat digunakan untuk proses pembelajaran.

Penilaian kelayakan media pembelajaran berbasis video pada mata pelajaran Teori Pemesinan Frais dilaksanakan oleh ahli media dinilai berdasarkan empat aspek yaitu aspek visual, desain, bahasa dan tipografi serta pemrograman. Data hasil penilaian ahli media dilihat pada Tabel 3.

Tabel 3. Hasil Penilaian Tiap Aspek oleh Ahli Media

\begin{tabular}{llcc}
\hline No. & \multicolumn{1}{c}{ Aspek } & $\begin{array}{c}\text { Persentase } \\
(\%)\end{array}$ & Klasifikasi \\
\hline 1. & Visual & 90 & Sangat Baik \\
2. & Desain & 70 & Baik \\
3. & Bahasa dan & 85 & Sangat Baik \\
& Tipografi & & \\
4. & Pemrograman & 75 & Baik \\
\hline & Rata-rata & 80 & Sangat Baik \\
\hline
\end{tabular}

Hasil persentase kelayakan media yang diperoleh dari ahli media untuk aspek visual adalah sebesar $90 \%$ termasuk pada klasifikasi sangat baik, untuk persentase kelayakan aspek desain adalah sebesar $70 \%$ termasuk pada klasifikasi baik, untuk persentase kelayakan aspek bahasa dan tipografi adalah sebesar $85 \%$ termasuk pada klasifikasi sangat baik dan persentase kelayakan aspek pemrograman adalah sebesar $75 \%$ termasuk pada klasifikasi baik. Hasil penilaian ahli media untuk penilaian seluruh aspek didapatkan hasil sebesar $80 \%$ dengan klasifikasi sangat baik dan disimpulkan bahwa media pembelajaran dinyatakan layak atau dapat digunakan untuk proses pembelajaran.

Penilaian kelayakan media pembelajaran oleh guru pengampu mata pelajaran teori pemesinan frais dinilai berdasarkan lima aspek yaitu aspek pendahuluan, isi materi, komunikasi, desain dan format sajian. Data hasil penilaian guru pengampu dapat dilihat pada Tabel 4.

Hasil persentase kelayakan media yang diperoleh dari penilaian guru pengampu untuk aspek pendahuluan adalah sebesar $75 \%$ termasuk pada klasifikasi baik, untuk persentase kelayakan aspek isi materi adalah 
sebesar $75 \%$ termasuk pada klasifikasi baik, untuk aspek komunikasi adalah sebesar $81.25 \%$ termasuk pada klasifikasi sangat baik, untuk persentase kelayakan aspek desain adalah sebesar $75 \%$ termasuk pada klasifikasi baik dan untuk persentase kelayakan aspek format sajian adalah sebesar $75 \%$ termasuk pada klasifikasi baik. Hasil penilaian guru pengampu untuk penilaian seluruh aspek didapatkan hasil sebesar $76.25 \%$ dengan klasifikasi sangat baik dan disimpulkan bahwa media pembelajaran berbasis video pada Teori Pemesinan Frais dinyatakan layak atau dapat digunakan untuk proses pembelajaran.

Tabel 4. Hasil Penilaian Tiap Aspek oleh Guru

\begin{tabular}{llcl}
\multicolumn{4}{c}{ Pengampu } \\
\hline No. & \multicolumn{1}{c}{ Aspek } & Persentase $(\%)$ & Klasifikasi \\
\hline 1. & Pendahuluan & 75 & Sangat Baik \\
2. & Isi Materi & 75 & Sangat Baik \\
3. & Komunikasi & 81.25 & Sangat Baik \\
4. & Desain & 75 & Sangat Baik \\
5. & Format Sajian & 75 & Sangat Baik \\
\hline & Rata-rata & 76.25 & Sangat Baik \\
\hline
\end{tabular}

Media pembelajaran berbasis video diujicobakan terhadap 32 siswa kelas XI TP 3 SMK N 2 Yogyakarta untuk memperoleh respon penilaian siswa dan terdiri dari tiga aspek yaitu aspek komunikasi, desain dan manfaat. Data hasil respon penilaian siswa dapat dilihat pada Tabel 5.

Tabel 5. Hasil Penilaian Tiap Aspek oleh Siswa

\begin{tabular}{clcl}
\hline No. & \multicolumn{1}{c}{ Aspek } & $\begin{array}{c}\text { Persentase } \\
(\%)\end{array}$ & Klasifikasi \\
\hline 1. & Komunikasi & 83.33 & Sangat Setuju \\
2. & Desain & 77.54 & Sangat Setuju \\
3. & Manfaat & 80.70 & Sangat Setuju \\
\hline & Rata-rata & 80.52 & Sangat Setuju \\
\hline
\end{tabular}

Hasil persentase kelayakan media yang diperoleh dari respon penilaian siswa untuk aspek komunikasi adalah sebesar 83.33\% termasuk pada klasifikasi sangat setuju, untuk persentase kelayakan aspek desain adalah sebesar $77.54 \%$ termasuk pada klasifikasi sangat setuju dan untuk persentase kelayakan aspek manfaat adalah sebesar $80.70 \%$ termasuk pada klasifikasi sangat setuju. Hasil penilaian respon siswa untuk penilaian seluruh aspek didapatkan hasil sebesar $80.52 \%$ dengan klasifikasi sangat setuju dan disimpulkan bahwa media pembelajaran dinyatakan layak atau dapat digunakan untuk proses pembelajaran.

\section{Rata-rata Total Penilaian Media Pembelajaran}

Rata-rata persentase pencapaian hasil validasi dari ahli materi dan ahli media, penilaian guru pengampu serta hasil penilaian dari siswa terhadap media pembelajaran berbasis video pada mata pelajaran Teori Pemesinan Frais dapat dilihat pada Tabel 6.

Tabel 6. Hasil Rata-rata Total Penilaian Media Pembelajaran

\begin{tabular}{clcr}
\hline No. & \multicolumn{1}{c}{ Aspek } & Persentase $(\%)$ & Klasifikasi \\
\hline 1. & Ahli Materi & 96.50 & Sangat Baik \\
2. & Ahli Media & 80.63 & Sangat Baik \\
3. & Guru Pengampu & 76.25 & Sangat Baik \\
4. & Respon Siswa & 80.52 & Sangat Baik \\
\hline & Rata-rata & 83.47 & Sangat Baik \\
\hline
\end{tabular}

Hasil persentase kelayakan media yang diperoleh dari validasi ahli materi adalah sebesar $96.50 \%$ termasuk pada klasifikasi sangat baik, untuk persentase kelayakan validasi ahli media adalah sebesar $80.63 \%$ termasuk pada klasifikasi sangat baik, untuk persentase kelayakan penilaian guru pengampu adalah sebesar $76.25 \%$ termasuk pada klasifikasi sangat baik, untuk persentase kelayakan respon penilaian siswa adalah $80.52 \%$ dengan klasifikasi sangat baik. Jadi, didapatkan rata-rata total penilaian media pembelajaran sebesar $83.47 \%$ dengan klasifikasi sangat baik dan disimpulkan bahwa media pembelajaran dinyatakan layak atau dapat digunakan untuk proses pembelajaran.

\section{SIMPULAN}

Bentuk produk media pembelajaran pada mata pelajaran teori pemesinan frais adalah media pembelajaran berbasis video dengan materi teori roda gigi heliks. Terdapat 
lima pokok bahasan dalam media yang dikembangkan yaitu: (1) tujuan pembelajaran; (2) pengertian roda gigi heliks; (3) bagianbagian roda gigi heliks; (4) fungsi roda gigi heliks; (5) proses pembuatan roda gigi heliks. File media pembelajaran berbasis video pada mata pelajaran teori pemesinan frais sebesar $166 \mathrm{MB}$ dengan format .mp4 dan dilengkapi dengan music pengantar, animasi serta narator.

Kelayakan media pembelajaran pembuatan roda gigi heliks pada mata pelajaran teori pemesinan frais diperoleh ratarata total penilaian media pembelajaran sebesar 83.22\% dengan klasifikasi sangat baik. Dengan demikian disimpulkan bahwa media pembelajaran pembuatan roda gigi heliks dinyatakan layak atau dapat digunakan untuk proses pembelajaran.

\section{DAFTAR RUJUKAN}

Arief S Sadiman, dkk. (1986). Media Pendidikan. Jakarta: CV. Rajawali.

Depdiknas. (2003). Undang-undang RI Nomor 20 Tahun 2003 Tentang Sistem
Pendidikan Nasional Pasal 15. Biro Jakarta: Biro Hukum.

Imam Mustholiq, dkk. (2007). Pengembangan Media Pembelajaran Interaktif Berbasis Multiedia Pada Mata Kuliah Dasar Listrik. Jurnal Pendidikan Teknologi dan Kejuruan, Vol. 16, No. 1, 1-18.

Istanto Wahyu Djatmiko, dkk. (2013). Pendidikan Teknologi dan Kejuruan. Yogyakarta: Fakultas Teknik Universitas Negeri Yogyakarta.

Nana Sudjana \& Ahmad Rivai. (2013). Media Pengajaran. Bandung: Sinar Baru Algensindo.

Sugiyono. (2011). Metode Penelitian Administrasi. Bandung: Alfabeta.

Sukoco, dkk. (2014). Pengembangan Media Pembelajaran Interaktif Berbasis Komputer Untuk Peserta Didik Mata Pelajaran Teknik Kendaraan Ringan. Jurnal Pendidikan Teknologi dan Kejuruan, Vol. 22, No. 2, 215-226.

Wina Sanjaya. (2012). Media Komunikasi Pembelajaran. Jakarta: Prenadamedia Group. 